\title{
Perspective of gene therapy with replication competent viruses
}

\author{
Makoto Maemondo \\ Division of Pulmonary Medicine, Allergy and Rheumatology, Iwate Medical University, Iwate, Japan \\ Correspondence to: Makoto Maemondo, MD, PhD. Division of Pulmonary Medicine, Allergy and Rheumatology, Iwate Medical University, 2-1-1 \\ Idaidori, Yahaba-cho, Shiwa-gun, Iwate 028-3695, Japan. Email: maemondo-ma693@aioros.ocn.ne.jp. \\ Comment on: Schenk EL, Mandrekar SJ, Dy GK, et al. A Randomized Double-Blind Phase II Study of the Seneca Valley Virus (NTX-010) versus \\ Placebo for Patients with Extensive-Stage SCLC (ES SCLC) Who Were Stable or Responding after at Least Four Cycles of Platinum-Based \\ Chemotherapy: North Central Cancer Treatment Group (Alliance) N0923 Study. J Thorac Oncol 2020;15:110-9.
}

Submitted Apr 09, 2020. Accepted for publication Jun 09, 2020.

doi: $10.21037 /$ tlcr-20-547

View this article at: http://dx.doi.org/10.21037/tlcr-20-547

\section{Background}

Although there have been many breakthroughs in cancer immunotherapy, including the discovery of immune checkpoint inhibitors, gene therapy has been evaluated as a cancer treatment strategy for well over two decades. Before the advent of CRISPR-Cas9 genome editing, viral vectors were used to deliver potential gene therapies. These vectors include retrovirus, lentivirus, adenovirus, and adenoassociated virus. Among them, adenovirus vectors have frequently been used in lung cancer clinical trials; while delivery of the p53 tumor suppressor gene was a thriving research area in the 1990s, this approach did not ultimately produce satisfactory results (1-3). The first viral therapy with potential for tumor-specific replication exploited an adenovirus serotype 5 (Ad5) in which the E1B $55 k D a$ gene had been deleted. Called Onyx-015, this virus theoretically replicates in p53-deficient cancer cells, but not normal cells that express wild type p53 (4). Replication-competent vectors have also been modified with lung-specific promoters in order to increase their specificity for lung cancer (5). After several clinical trials failed to show clinical efficacy $(6,7)$, the development of this Ad5 serotype was terminated. Since then, other serotypes such as ColoAd1, which has specificity for colorectal cancer, have been developed (8).

\section{Seneca Valley Virus}

Seneca Valley Virus Isolate 001 (SVV-001) may be used for cancer gene therapy since it can induce tumor cell lysis following intravenous administration. The virus belongs to the Picornavirus family, replicates via RNA in infected cells, and does not integrate into the host cell genome; this is important from a safety standpoint, since it cannot cause unexpected modifications of host nuclear genes. Discovered in 2002 by Genetic Therapy Inc. and found in pigs and cattle, there is no evidence that this virus causes any harmful disease in humans (9). Systemic delivery of oncolytic viruses is necessary to treat patients with metastatic cancer. There are some difficulties associated with systemic delivery of oncolytic viruses, such as toxicity to normal cells and inactivation by human blood components such as virus neutralizing antibodies $(10,11)$.

A promising feature of SVV-001 is that the virus has a high affinity for neuroendocrine cells. Cell lines with neuroendocrine features such as small cell lung carcinoma (SCLC) are more sensitive to the cytolytic activity of SVV-001 than any of the normal adult human cells. The infectivity of SVV-001 is not attenuated by human blood components, and the virus is well tolerated and shows no dose limiting toxicity in immunocompetent mice (9).

\section{Phase I study of SVV-001}

A phase I study using SVV-001 in advanced SCLC has been carried out by Rudin et al. (12). The trial included six patients with SCLC and 24 with mixed neuroendocrine tumors of which six had carcinoid tumors. This study confirmed the replication, efficacy, and safety of SVV001 following intravenous administration across five $\log$-increments from $10^{7}$ to $10^{11}$ viral particles $/ \mathrm{kg}$. Virus clearance mediated by anti-viral antibodies was found in 
all patients. The recommended dose was $10^{11} \mathrm{vp} / \mathrm{kg}$ of the maximum dose of virions/body due to lack of dosedependent toxicity.

\section{Phase II study of SVV-001}

A phase II trial was reported to 7 TO by Schenk et al. in 2020 (13). Patients with extensive disease (ED)-SCLC after four or more cycles of platinum doublets were randomized to groups that received either a single dose of $10^{11} \mathrm{SVV}$ 001 particles/kg or placebo. The primary endpoint was progression free survival (PFS). Although a total sample size of 99 patients was planned, this trial was terminated for futility after 40 events following a preplanned interim analysis. The median PFS was 1.7 months for the SVV-001 group versus 1.7 months for the placebo group [hazard ratio $(\mathrm{HR})=1.03, \mathrm{P}=0.92]$, meaning that single dose SVV-001 treatment was not efficacious. The median overall survival (OS) was inferior in the SVV-001 group compared to the placebo group (6.6 versus 13.2 months; $\mathrm{HR}=1.49, \mathrm{P}=0.23$ ). No remarkable toxicities were observed, though fatigue and flu-like symptoms increased in patients who received SVV001. Serum virus titers were evaluated at 48 h, 7 days and 14 days after SVV-001 administration. The serum detection rate gradually decreased from $84.6 \%$ at $48 \mathrm{~h}$, to $26.9 \%$ at 7 days and $23.0 \%$ at 14 days.

Contrary to expectation, patients who remained seropositive for the virus on days 7 and 14 had significantly lower PFS than in whom virus could not be detected.

There are several elements that might help explain this counterintuitive result. First, antiviral antibody levels were evaluated 14 days after dosing of SVV-001. Neutralizing antiviral antibodies were detected 14 days after treatment in all 23 patients who received SVV-001. From these results, it is not clear whether the presence of antiviral antibodies affects virus clearance or virus therapeutic efficacy. The Schenk article did not report antibody levels in individual patients, and therefore the effects of antiviral antibody levels on viral clearance and therapeutic efficacy cannot be deduced. A phase I study of SVV-001 in pediatric tumors with neuroendocrine features has evaluated the relationship between anti-virus antibodies and blood virus levels (14). Antiviral antibodies developed in 11 of 12 cases. The speed of viral clearance from the serum of the patient in whom viral antibodies were not detected was not significantly different from that of the other patients. Furthermore, antitumor effects were not observed in any of the patients, and development of SVV-001 therapy for pediatric tumors was stopped after this trial. The relationship between antiviral antibodies and serum virus clearance remains unclear. In the phase 2 SCLC trial, all patients developed antiviral antibodies, whereas clearance of serum virus was observed only in $70-80 \%$ of cases (13). The effect of antiviral antibody levels on viral clearance and therapeutic efficacy was not evaluated in detail in this study, however. We suggest that the release of data addressing this last point would greatly help our understanding of this intricate relationship.

Next, it is important to determine whether the virus actually replicates in the target tumor, since it is this activity that ultimately leads to oncolysis. In a phase 1 study conducted by Rudin et al., virus was detected by immunohistochemical analysis in liver metastatic sites but not in the normal liver site resected from patients who died of progressive disease on day 28 after SVV001 administration (12). Detection of virus and viral replication in tumors were not evaluated in this phase 2 study by Schenk et al. This is important, as we need to know the association between the distribution of the virus to the tumor and the serum virus level. Higher serum virus levels do not always result in higher virus replication in tumors. In the Schenk phase 2 study, patients with serum virus clearance had comparable PFS and slightly longer OS compared to patients in whom there was persistence of virus in the serum. Miles et al. reported that interferon-alfa and -beta, which are key mediators of innate immunity, suppressed SVV-001 cell infection (15). It is possible that innate immunity may not function properly if the virus remains in the serum, which may in turn explain the short OS.

This phase II study at SCLC was completely negative. Although there is academic interest in replicating SVV001, clinical development of SVV-001 therapy in SCLC has stagnated. In addition to SSV-001 and adenovirus, several new replication-competent viruses have now been created. The failure of SSV-001 and adenovirus in clinical trials has had a significant impact on the future development of the replication competent virus. In developing replication competent virus therapy, there are still many hurdles to overcome. These include determining whether systemic administration can provide tumor specificity and whether the virus effectively replicates in target tumor cells.

\section{Acknowledgments}

\section{Funding: None.}




\section{Footnote}

Provenance and Peer Review: This article was commissioned by the editorial office, Translational Lung Cancer Research. The article did not undergo external peer review.

Conflicts of Interest: The author has completed the ICMJE uniform disclosure form (available at http://dx.doi. org/10.21037/tlcr-20-547). The author has no conflicts of interest to declare.

Ethical Statement: The author is accountable for all aspects of the work in ensuring that questions related to the accuracy or integrity of any part of the work are appropriately investigated and resolved.

Open Access Statement: This is an Open Access article distributed in accordance with the Creative Commons Attribution-NonCommercial-NoDerivs 4.0 International License (CC BY-NC-ND 4.0), which permits the noncommercial replication and distribution of the article with the strict proviso that no changes or edits are made and the original work is properly cited (including links to both the formal publication through the relevant DOI and the license). See: https://creativecommons.org/licenses/by-nc-nd/4.0/.

\section{References}

1. Roth JA, Swisher SG, Merritt JA, et al. Gene therapy for non-small cell lung cancer: a preliminary report of a phase I trial of adenoviral p53 gene replacement. Semin Oncol 1998;25:33-7.

2. Guan YS, Liu Y, Zou Q, et al. Adenovirus-mediated wildtype $\mathrm{p} 53$ gene transfer in combination with bronchial arterial infusion for treatment of advanced non-small-cell lung cancer, one year follow-up. J Zhejiang Univ Sci B 2009; 10:331-40.

3. Ning $X$, Sun Z, Wang Y, et al. Docetaxel plus transtracheal injection of adenoviral-mediated p53 versus docetaxel alone in patients with previously treated nonsmall-cell lung cancer. Cancer Gene Ther 2011;18:444-9.

4. Heise C, Sampson-Johannes A, Williams A, et al. ONYX015, an E1B gene-attenuated adenovirus, causes tumorspecific cytolysis and antitumoral efficacy that can be augmented by standard chemotherapeutic agents. Nat Med 1997;3:639-45.

5. Maemondo M, Saijo Y, Narumi K, et al. Gene therapy with secretory leukoprotease inhibitor promotercontrolled replication-competent adenovirus for non-small cell lung cancer. Cancer Res 2004;64:4611-20.

6. Yu DC, Working P, Ando D. Selectively replicating oncolytic adenoviruses as cancer therapeutics. Curr Opin Mol Ther 2002;4:435-43.

7. Reid T, Warren R, Kirn D. Intravascular adenoviral agents in cancer patients: lessons from clinical trials. Cancer Gene Ther 2002;9:979-86.

8. Kuhn I, Harden P, Bauzon M, et al. Directed evolution generates a novel oncolytic virus for the treatment of colon cancer. PLoS One 2008;3:e2409.

9. Reddy PS, Burroughs KD, Hales LM, et al. Seneca Valley virus, a systemically deliverable oncolytic picornavirus, and the treatment of neuroendocrine cancers. J Natl Cancer Inst 2007;99:1623-33.

10. Morrissey RE, Horvath C, Snyder EA, et al. Rodent nonclinical safety evaluation studies of SCH 58500 , an adenoviral vector for the $\mathrm{p} 53$ gene. Toxicol Sci 2002;65:266-75.

11. Chen Y, Yu DC, Charlton D, et al. Pre-existent adenovirus antibody inhibits systemic toxicity and antitumor activity of CN706 in the nude mouse LNCaP xenograft model: implications and proposals for human therapy . Hum Gene Ther 2000;11:1553-67.

12. Rudin CM, Poirier JT, Senzer NN, Stephenson J Jr, et al. Phase I clinical study of Seneca Valley Virus (SVV-001), a replication-competent picornavirus, in advanced solid tumors with neuroendocrine features. Clin Cancer Res 2011;17:888-95.

13. Schenk EL, Mandrekar SJ, Dy GK, et al. A Randomized Double-Blind Phase II Study of the Seneca Valley Virus (NTX-010) versus Placebo for Patients with Extensive-Stage SCLC (ES SCLC) Who Were Stable or Responding after at Least Four Cycles of Platinum-Based Chemotherapy: North Central Cancer Treatment Group (Alliance) N0923 Study. J Thorac Oncol 2020;15:110-9.

14. Burke MJ, Ahern C, Weigel BJ, et al. Phase I trial of Seneca Valley virus (NTX-010) in children with relapsed/ refractory solid tumors: a report of the Children's Oncology Group. Pediatr Blood Cancer 2015;62:743-50.

15. Miles LA, Burga LN, Gardner EE, et al. Rudin Anthrax toxin receptor 1 is the cellular receptor for Seneca Valley virus. J Clin Invest 2017;127:2957-67.

Cite this article as: Maemondo M. Perspective of gene therapy with replication competent viruses. Transl Lung Cancer Res 2020;9(6):2511-2513. doi: 10.21037/tlcr-20-547 